\title{
COMPARATIVE DIAGNOSIS OF TYPHOID FEVER BY POLYMERASE CHAIN REACTION AND WIDAL TEST IN SOUTHERN DISTRICTS (BANNU, LAKKI MARWAT AND D.I.KHAN) OF KHYBER PAKHTUNKHWA, PAKISTAN
}

\author{
Irfan Ullah Khan $^{1 *}$, Sanaullah Sajid ${ }^{2}$, Asad Javed ${ }^{2}$, Sedra Sajid ${ }^{1}$, Shafi Ullah Shah ${ }^{1}$, Shahid Niaz Khan ${ }^{1}$, Kalim Ullah ${ }^{1}$ \\ ${ }^{1}$ Department of Zoology, Kohat University of Science and Technology, Kohat, Pakistan \\ ${ }^{2}$ Institute of Microbiology, Faculty of veterinary science, University of Agriculture, Faisalabad, Pakistan \\ Corresponding author emial: irfanmarwat20@gmail.com
}

This is an open access article distributed under the Creative Commons Attribution License, which permits unrestricted use, distribution, and reproduction in any medium, provided the original work is properly cited.

\begin{tabular}{|c|c|}
\hline ARTICLE DETAILS & ABSTRACT \\
\hline Article history: & Typhoid fever is a major dilemma in developing nations, despite the antibiotic use and new antibiotics discovery. \\
\hline Received 19 October 2017 & Blood culture and serological tests (especially Widal test) that are regularly performed in Pakistan for diagnosis \\
\hline Accepted 19 October 2017 & $\begin{array}{l}\text { provide objectionable levels of false negative and false positive results, respectively. The present study was carried } \\
\text { out at Kohat University of science and technology, Kohat, Pakistan from January } 2013 \text { to December } 2013 \text {. A }\end{array}$ \\
\hline Available online 25 October 2017 & polymerase chain reaction (PCR) assay was compared with Widal test and blood culture for blood samples of 96 \\
\hline Keywords: & $\begin{array}{l}\text { patients. In this study, blood from } 25 \text { healthy individuals was collected as a negative control. The detection rate of PCR } \\
\text { was maximum }(64.5 \%) \text { followed by Widal test }(26 \%) \text { and blood culture }(14.5 \%) \text {. Among the } 82(85.4 \%) \text { samples that }\end{array}$ \\
\hline Widal test, PCR, Blood culture, & were found negative with blood culture, 48 (58.5\%) were successfully detected by PCR and $11(13.4 \%)$ were positive \\
\hline Typhoid fever, Salmonella typhi & for the Widal test. Findings of this study showed that PCR is a fast and reliable technique for diagnosis of typhoid fever \\
\hline
\end{tabular}

\begin{abstract}
1. INTRODUCTION
Typhoid fever is one of the major leading causes of mortality across the world. Typhoid fever is caused by a bectrium Salmonella typhi. Salmonella typhi is aerobic, non-spore-forming, flagellated bacilli, that belonges to genus Salmonella which is a member of Enterobacteriaceae family of Gram negative bacteria. The cells of Salmonella typhi are rod shaped 2-3 $\mu \mathrm{m}$ long and 0.4-0.6 $\mu \mathrm{m}$ diameter [1]. Salmonella typhi is a highly adapted humanspecific pathogen [2], and the illness caused by this bacterium is a serious public health concern, particularly in developing countries [3]. In economically weak countries, the typhoid fever continues to be endemic, although it has been eradicated from economically stable and developed nations by well-organized sanitation and hygienic water supply. It is a lethal disease in human populations, transmitted due to the contaminated water and food supplies [4].
\end{abstract}

Some of the common signs and symptoms of typhoid include high fever $\left(39-40^{\circ} \mathrm{C}\right)$, profuse sweating, headache, muscular pain, abdominal bloating, discomfort, nausea, vomiting, loss of appetite, diarrhea or constipation, fatigue, exhaustion, gastroenteritis, abdominal pain and enteric [5-12].

The key way through which typhoid kills, is by perforation of the small intestine, into the abdominal cavity. This condition is called peritonitis and is often fatal. Other complications of typhoid occur when a large number of bacteria get into the bloodstream, causing bacteremia. They can travel to the lungs, causing pneumonia or to the lining of the brain (meningitis), the bones (osteomyelitis), the heart valves (endocarditis), the kidneys (glomerulonephritis), the genital or urinary tract, the muscles and to the liver (hepatitis) [13-17].

Various techniques are being used for the diagnosis of typhoid fever such as cultural technique, serological test, biochemical test and molecular technique. The widely used diagnostic practices include Widal test and blood culture because these methods are inexpensive while the other methods are invasive, tedious, and time consuming and so expensive [18]. The Widal test has been found nonspecific and difficult to interpret the results in those areas where typhoid fever is endemic [19, 20]. Rapid detection methods such as the use of DNA or RNA probes and immunedetection methods have also been developed but these methods are rare with regard to sensitivity and specificity [21,22]. The Polymerase chain reaction (PCR) technology has the potential to solve all these problems. For rapid diagnosis and sensitive detection, the PCR technique is ideal because this method has the potential to amplify target gene or DNA from a single copy $[23,24]$.

Typhoid fever is a fatal disease in Pakistan. The objective of this study was to investigate the incidence of typhoid fever and development of PCR assay by amplification of the flagellin gene of Salmonella typhi in patients from three Southern Districts (Bannu, Lakki Marwat and D.I.Khan) of Khyber Pakhtunkhwa (KPK). Our selected districts were based on high prevalence of typhoid fever. Clinical diagnosis of patients was done using Widal test, blood culture and Polymerase Chain Reaction and their results were compared.

This assay could be used as a tool to reinforce the clinical diagnosis of typhoid fever. It could also play a significant role in treatment, prevention, and future planning regarding typhoid fever in Pakistan.

\section{MATERIAL AND METHOD}

\subsection{Clinical samples and negative controls}

All the districts selected for this study were based on the high prevalence of typhoid and due to other reasons, such as poor health and low socioeconomic status of the people in the region. Total 96 blood samples were collected from typhoid patients from January 2013 to December 2013. Approximately $10 \mathrm{ml}$ of blood specimen was collected from patients in sterile syringe. $4 \mathrm{ml}$ of the blood specimen was directly used for blood culture, $2 \mathrm{ml}$ was placed in a tube for extracting DNA, rest of the fresh blood was centrifuged on the same day and the collected serum was stored at $4^{\circ} \mathrm{C}$ until used for the Widal test. Samples were also collected from 25 healthy people with no recent history of fever within the previous 6 months.

\subsection{Gram staining and biochemical test}

For gram staining and biochemical characterization of S. Typhi, $4 \mathrm{ml}$ of fresh blood was added to $12 \mathrm{ml}$ of bile broth and incubated for $24 \mathrm{~h}$ at $37^{\circ} \mathrm{C}$. From the overnight culture, $1 \mathrm{ml}$ sample was then spread on Salmonella Shigella agar plate. After incubation for $24 \mathrm{~h}$ at $37^{\circ} \mathrm{C}$, colonies were examined by Gram staining and the biochemical tests were performed to identify S. Typhi positive cultures.

\subsection{Widal test}

Widal test was performed according to the manufacturer's protocol (Murex Biotech, Dartford, UK). For that purpose, two fold serial dilutions (1:201:1280) of the serum sample were prepared and one drop (about 20 $\mu$ l) of 0 antigen suspension was added to each tube containing the diluted sample. Then each tube was gently mixed and incubated for 4 hours at $50^{\circ} \mathrm{C}$ in order to check the agglutination. According to routine diagnostic criteria, a titer of 1:320 or more was considered positive.

\subsection{Bacterial strains and DNA extraction}

Strains of 10 species of Salmonella and other organisms, including Salmonella paratyphoid A, B, C, Salmonella typhimurium, Salmonella 
cholerasius, Salmonella enteritidis, Escherichia coli, Klebsiella pneumoniae, Enterobacter happier and Proteus mirabilis were obtained from different diagnostic centres. These strains were used for testing the specificity and sensitivity of the PCR assay, and one pure strain of Salmonlla typhi was used as a reference strain for the standardization of PCR conditions. All of the bacterial strains were grown overnight in Brain Heart Infusion agar (Oxoid, Basingstoke, UK) and then subjected to DNA extraction.

Genomic DNAs from the cultured bacteria and the blood specimens for PCR were extracted according to the protocol using a QIAamp blood mini kit (Qiagen, Hilden, Germany). The purity of the extracted DNA was checked by spectrophotometer (ratio of A260/A280), Nanodrop and agarose gel electrophoresis.

\subsection{PCR primers and Amplification strategy}

Already reported oligonucleotide primers were used in this study, which was first reported by Song et al. [3]. The sequence of the forward primer (ST1) was 5 -ACT GCT AAA ACC ACT ACT 3 (nucleotides 1060 to 1077 in the sequence of GenBank accession number L21912) and that of the reverse primer (ST4) was 5 -TGG AGA CTT CGG TCG CGT AG- 3 (nucleotides 1407 to 1426 in the sequence of GenBank accession number L21912). These primers could amplify a $367 \mathrm{bp}$ fragment of the flagellin gene.

PCR amplification of the flagellin gene was done by making PCR mixture $(50 \mu \mathrm{l})$ contained $1 \mu \mathrm{l}$ bacterial DNA, $5 \mu \mathrm{l} 10 \mathrm{X}$ Taq DNA polymerase Buffer, $5 \mu \mathrm{l} \mathrm{MgCl} 2(25 \mathrm{mM}), 1 \mu \mathrm{ldNTPs}(10 \mathrm{mM}$ each), $0.2 \mu \mathrm{l} \mathrm{Taq}$ DNA Polymerase $(5 \mathrm{U} / \mu \mathrm{l}), 1 \mu \mathrm{l}$ Forward primer $(10 \mathrm{pmol})$ and $1 \mu \mathrm{l}$ reverse primer $(10$ pmol). The mixture was amplified with initial denaturation at $94^{\circ} \mathrm{C}$ for 5 minutes, followed by 30 cycles condition at $94^{\circ} \mathrm{C}$ for 45 seconds, $55^{\circ} \mathrm{C}$ for 45 seconds, $72^{\circ} \mathrm{C}$ for 45 seconds and the final extension at $72^{\circ} \mathrm{C}$ for $10 \mathrm{~min}$. PCR amplification was performed using Touchgene $®$ gradient PCR system TC-512 (Techne, Cambridge, UK). An aliquot of $8 \mu$ l of each amplified product was run on gel electrophoresis in $1.5 \%$ (wt/vol) agarose gel, with a DNA molecular weight marker (VC 100bp Plus Vivantis ${ }^{\circledR}$ ) in parallel. Electrophoresis was performed in tris-Boric acid ethylenediaminetetraacetic acid (EDTA) buffer (TBE buffer) at $100 \mathrm{~V}$ for 45 min. The gel was stained with ethidium bromide $(0.5 \mu \mathrm{g} / \mathrm{ml})$ for $25 \mathrm{~min}$, rinsed with distill water and observe the results under UV illuminator to obtain 367 bp PCR product.

\section{RESULTS}

\subsection{Biochemical tests for Salmonella typhi}

For biochemical characterization, a series of biochemical tests for Salmonella typhi was performed, such as Citrate, Catalase, Motality, Indole, Vogas-Proskauer (VP), Kilgler iron agar (KIA), Triple sugar iron (TSI), Litmus Milk, Oxidase and Nitrate as shown in the table 1.

Table 1: Biochemical characteristics of salmonella typhi

\begin{tabular}{|c|c|c|}
\hline Test & Results & Change in growth media \\
\hline Citrate & + & Green to blue \\
\hline Catalase & + & More bubble formation \\
\hline Motality & + & Turbidity in test tube Zig/Zag growth \\
\hline Indole & - & Only band on top not red in colour \\
\hline $\begin{array}{c}\text { Vogas- } \\
\text { Proskauer }\end{array}$ & - & Brown to yellow, oily ring appeared \\
\hline Oxidase & - & Filter paper remain white \\
\hline Nitrate & + & Blue red colour appear \\
\hline KI & $\begin{array}{c}\text { Slope, Butt, H2S, } \\
\text { Gas }\end{array}$ & Brown to pink, brown,, \pm \pm \\
\hline Litmus Milk & + & Coagulation, peptonisation \\
\hline TSI & $\begin{array}{c}\text { Slant, Butt, H2S, } \\
\text { Gas }\end{array}$ & Light pink (alkaline), light pink-yellow (alkaline-acidic) \pm \\
\hline
\end{tabular}

Salmonella typhi were found positive for Nitrate, Citrate utilization, Motality, Litmus milk and Catalase. On KIA, Salmonella typhi produced brown pink slope and yellow butt indicating fermentation of glucose but not lactose and indicated the test as positive. In TSI, the organism produced light pink (alkaline) slant and yellow butt with the production of H2S gas, indicated positive test. Salmonella typhi were found negative for Oxidase, Indole and Vogas-Proskauer test.

\subsection{Specificity of the PCR assay}

To test the specificity of the primers for Salmonella typhi, PCR was carried out with extracted DNA from six Salmonella strains and four other bacteria, using the same PCR conditions. With this primer, an expected 367 bp PCR amplified product was obtained only with Salmonella typhi strains. None of the other strains, which are closely related to Salmonella typhi, showed this $367 \mathrm{bp}$ PCR product. Bacterial strains from four other genera tested in this study showed no amplification at all using this specific pair of primers (Figure. 1).

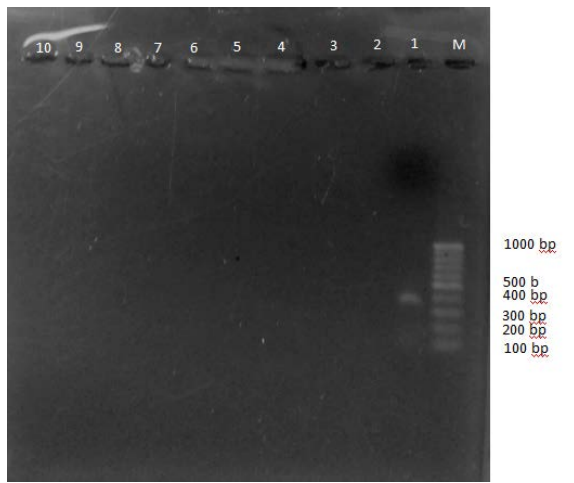

Figure 1: Agarose gel electrophoresis showing the specificity of polymerase chain reaction (PCR) for detection of flagellin gene of S. Typhi. Lane M shows molecular weight marker (VC 100bp Plus Vivantis ${ }^{\circledR}$ ), Lane 1 shows 367 bp amplified product of flagellin gene of S. Typhi, Lane 2 to 10 showing no amplification for DNA products of Salmonella paratyphoid A, B, C, Salmonella typhimurium, Salmonella enteritidis, Salmonella cholerasius, Enterobacter hapniae Escherichia coli, Klebsiella pneumonia and Proteus mirabilis respectively.

\subsection{Sensitivity of the PCR}

The sensitivity of PCR was determined by making serial dilutions ( 1 to $1 \mathrm{x}$ 107) of template DNA of the positive isolate. The quantification of these dilutions was calculated by using Nanodrop. All these dilutions were amplified with PCR by using Thermo Fisher Scientific Kit. These dilutions were then analyzed by $1.5 \%$ gel electrophoresis and interpreted the results under UV illuminator after staining with ethidium bromide. The amount of DNA that was detected on the gel after serial dilution and PCR was $10 \mathrm{fg}$ (Figure 2).

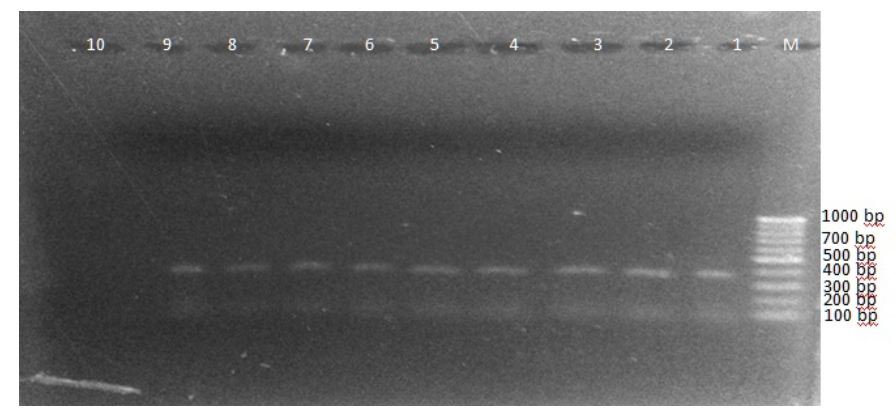

Figure 2: Sensitivity with serial diluted DNAs from Salmonella typhi. Lane M shows molecular weight marker (VC 100bp Plus Vivantis $($ ), lane 1 shows 367 bp S. typhi DNA $95.2 \mathrm{ng}$, lane 2 shows S. typhi DNA $9.7 \mathrm{ng}$, lane 3 shows S. typhi DNA $1.7 \mathrm{ng}$, lane 4 shows S. typhi DNA $0.8 \mathrm{ng}$, lane 5 shows $\mathrm{S}$. typhi DNA $0.2 \mathrm{ng}$, lane 6 shows S. typhi DNA $30 \mathrm{pg}$, lane 7 shows S. typhi DNA $1 \mathrm{pg}$, lane 8 shows S. typhi DNA $10 \mathrm{fg}$, lane 9 shows positive control of $367 \mathrm{bp}$, and lane 10 is negative control.

3.4 PCR, blood culture, and Widal test in patients with suspected typhoid fever and in healthy persons

Samples $(\mathrm{n}=25)$ was used as a negative control from healthy people who had no history of fever within the previous 6 months. PCR and blood culture were negative in all samples, however, we found $5(20 \%)$ positive cases on the Widal test with a titer of 1: 320 or more for Salmonella typhi 0 antigen (Figure 3). Out of the total 96 patients with suspected typhoid fever, $62(64.5 \%)$ patients were positive for the PCR assay, $14(14.5 \%)$ patients were positive for blood culture, and 25 (26\%) patients were positive for the Widal test (Figure 3).

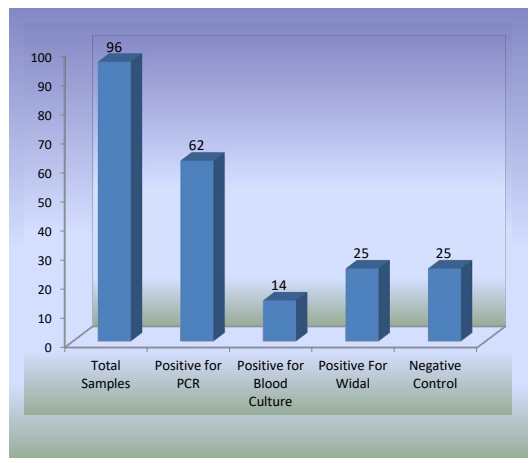

Cite this article as: Irfan Ullah Khan, Sanaullah Sajid, Asad Javed, Sedra Sajid, Shafi Ullah Shah, Shahid Niaz Khan, Kalim Ullah (2017). Comparative Diagnosis Of Typhoid Fever By Polymerase Chain Reaction And Widal Test In Southern Districts (Bannu, Lakki Marwat And D.I.Khan) Of Khyber Pakhtunkhwa, Pakistan. Acta Scientifica Malaysia, 1(2):12-15. 
Figure 3: Comparison of PCR, blood culture, and Widal test findings in patients with suspected typhoid fever and in healthy persons.

\subsection{Comparison between blood culture, widal test and polymerase chain reaction (PCR)}

Out of the 96 patients, only 14 (14.5\%) patients were positive for blood culture and $82(85.4 \%)$ patients were negative. All of the patients positive for blood culture were also positive for PCR and the Widal test (Figure 4). Out of the 82 patients negative for blood culture, 48 (58.5\%) patients were positive for PCR, and $11(13.4 \%)$ patients were positive for the Widal test (Figure 4).

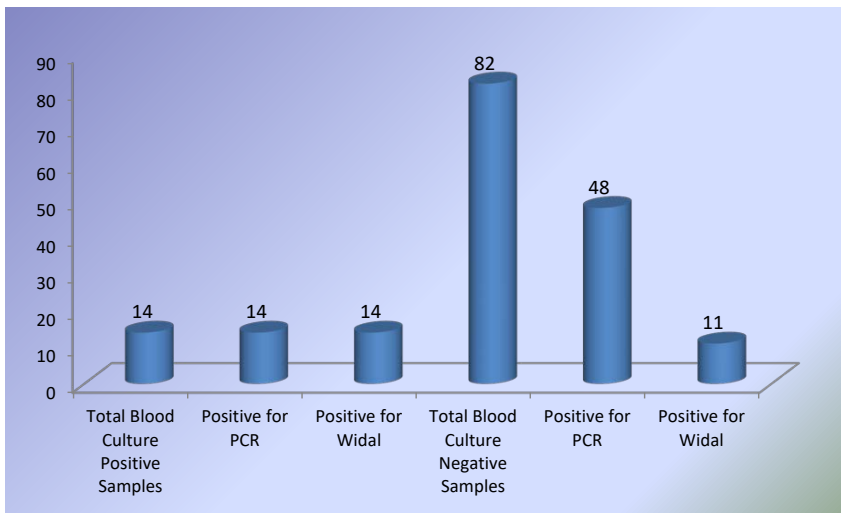

Figure 4: Comparison of PCR and Widal test findings in blood culture positive and negative patients.

\section{DISCUSSION}

A rapid and sensitive method for the detection of Salmonella typhi would help in relieving patients' suffering and would protect from the fatal complication of typhoid like perforation of the intestines and typhoid meningitis. The early and definitive diagnosis of typhoid fever can make possible specific treatment at an early stage of the disease, leading to rapid elimination of the pathogen and helping in the epidemiological investigation of food borne outbreaks [2]. The most preferential methods for the diagnosis of typhoid fever currently used are blood culture and the Widal test. Due to low cost, the Widal test is mostly used but it has some disadvantages like it cannot detect the disease at the early stage because specific antibodies take at least 1 week to reach detectable level. Along with that, it is nonspecific and particularly unreliable with single titers $[2$, $3]$. In the present study, Widal test was positive in $20 \%$ of healthy persons without clinical signs because these healthy persons were living in endemic areas. This finding suggested that the Widal test could give an unacceptable level of false positive results.

We found only $14.5 \%$ positivity for blood culture in this study, may be because of low bacteremia in most of our blood samples or because of other factors such as the bacterio static effect of antibiotics already administered to some patients before blood culture was done, the time of blood collection, the type of culture medium used, the host's immune response system and the intracellular characteristics of S. Typhi $[2,3,7,8,9]$. In this study, PCR assay detected positive results in $58.5 \%$ of the patients that were negative in blood culture although clinically suspected for typhoid fever. This finding indicated that the PCR assay could detect the $S$. Typhi infection from patients showing negative results for blood culture.

DNA probe hybridization methods can detect $\mathrm{S}$. Typhi, but their sensitivity is poor because they cannot detect fewer than 500 bacteria/m [10-13]. This problem of sensitivity could be circumvented by using the PCR, which can detect very small amounts of DNA by enzymatic amplification with absolute specificity within several hours. For PCR, we preferred to target the flagellin gene, because the flagellin gene of S. Typhi has unique nucleotide sequences in the hyper variable region of the gene $[3,16,17$, $18,19]$ which are different from those sequences in other strains of Salmonella. Our PCR assay using these primers of flagellin gene was specific for the S. Typhi strain. This PCR assay shows a positive result only with Salmonella typhi strain but not with other strains, because the other strains have no significant sequence homology with the primers that we used in this study. The sensitivity of this PCR assay was also high; this PCR could detect a positive result from $10 \mathrm{fg}$ of genomic DNA of Salmonella typhi, which corresponds to three to four bacteria of S. Typhi. This PCR assay was also very rapid and taking less than 10 hours, because there is no need to run the procedure again for nested PCR.

\section{CONCLUSION}

In conclusion, our results suggest that the PCR assay can be used as a rapid diagnostic method for the detection of typhoid fever, especially in endemic areas where the Widal test shows non-significant differences between patients with suspected typhoid fever and healthy individuals and where blood culture is negative because of prior antibiotic treatment. Therefore, the PCR assay can be of singular importance for the detection of early cases of typhoid, which is important not only for the treatment of patients but is also necessary for the control of the disease.

\section{REFERENCES}

[1] Bhan, M., Bahl, R., and Bhatnagar, S. 2005. Typhoid and paratyphoid fever. Lancet 366, 749-762.

[2] Naheed, A., Ram, P.K., Brooks, W.A., Hossain, M.A., Parsons, M.B., Talukder, K.A., Mintz, E., Luby, S., Breiman, R.F. 2010. Burden of typhoid and paratyphoid fever in a densely populated urban community, Dhaka, Bangladesh. International Journal of Infectious Diseases,14 (3), 93-99.

[3] Rathish, K.C., Chandrashekar, M.R., and Nagesha, C.N. 1995. An outbreak of multidrug resistant typhoid fever in Bangalore. The Indian Journal of Pediatrics, 62, 445-448.

[4] Cunha, B.A. 2004. Osler on typhoid fever, Differentiating typhoid from typhus and malaria. Infectious Disease Clinics of North America, 18 (1), 111-125.

[5] Nagashetty, K., Channappa, S.T., and Gaddad, S.M. 2010. Antimicrobial susceptibility of Salmonella Typhi in India. The Journal of Infection in Developing Countries,42, 070-073.

[6] Archer, D.L., and Young, F.E. 1988. Diseases with a food vector. Clinical Microbiology Review, 1, 377-398.

[7] Hargrett-Ban, N.T., Pavia, A.T., and Tauxe, R.V. 1988. Salmonella isolates from humans. Morbid Mortal Weekly Report Summary, 37, 25-31.

[8] Echeita, M.A., and Usera, M.A. 1989. Prevalence of Salmonella serotypes isolated in Spain from human and non-human sources. Microbiology, 5, 95-103.

[9] Rodrigue, D.C., Tauxe, E.V., Rowe, B. 1990. International increase in Salmonella Enteritidis. Epidemiology of Infection, 105, 21-27.

[10] Chiu, C.H., Su, L.H., and Chu, C. 2004. Salmonella enterica serotype Choleraesuis: epidemiology, pathogenesis, clinical disease, and treatment Clinical Microbiology Reviews, 4 (17), 311-322.

[11] Anna, E., Newton. 2014. 3 Infectious Diseases Related To Travel. CDC health information for international travel 2014. The Yellow Book. ISBN 9780199948499. Health Service.

Typhoid Fever. cdc.gov. May 14, 2013. Retrieved 28 March 2015.

[14] Typhoid fever. 2016. Centers for Disease Control and Prevention.

[15] Crump, J.A. 2010. Global trends in typhoid and paratyphoid fever. Clinical Infectious Diseases, 50, 241-244.

[16] Humphries, R.L. 2011. Current Diagnosis \& Treatment Emergency Medicine. 7thed.New York, N.Y.: The McGraw-Hill Companies.

[17] Longo, D.L. 2012. Harrison's Online, 18th ed. New York, N.Y.: The McGraw-Hill Companies.

[18] Haque, A., Ahmed, J., Qureshi, J.A. 1999. Early detection of typhoid fever by polymerase chain reaction. Annals of Saudi Medicine, 19, 337- 40.

[19] Song, J.H., Cho, H., Park, M.Y., Na, D.S., Moon, H.B., Pai, C.H. 1993. Detection of Salmonella typhi in the blood of patients with typhoid fever by polymerase chain reaction. Journal of Clinical Microbiology, 31, 1439-43.

[20] Chaudhry, R., Laxmi, B.V., Nisar, N., Ray, K., Kumar, D. 1997. Standardiza-tion of polymerase chain reaction for the detection of Salmonellatyphiin typhoid fever. Journal of Clinical Pathology, 50, 437-9.

[21] Zhu, Q., Lim, C.K., and Chan, Y.N. 1996. Detection of Salmonella typhi by polymerase chain reaction. Journal of Applied Microbiology, 80, 244-51. 
[22] Hashimoto, Y., Itho, Y., Fujinaga, Y., Khan, A.Q., Sultana, F., Miyake, Hirose, M. K., Yamamoto, H., and Ezaki, T. 1994. Development of nested PCR based on the ViaB sequence to detect Salmonella typhi. Journal of Clinical Microbiology, 33 (3), 775-777.

[23] Ali, W., Habib, M., Khan, R., Zia, M., Khan, I., Saliha, U., Farooq, M., Shah, M., and Muzammil, H. 2015. Reverse transcription-polymerase chain reaction (RT-PCR) based detection and economic impact of foot-andmouth disease in District Faisalabad, Pakistan during the year 2015.

[24] Ali, W., Habib, M., Sajid, S., Khan, A., Mazhar, M.U., Khan, I.U., Saliha, U., Farooq, M., Shah, M. and Muzammil, H.M. 2017. A Reverse transcriptionpolymerase chain reaction (RT-PCR) based detection of foot-and-mouth disease in District Faisalabad, Pakistan during the Year 2016. Matrix Science Medica 1 (1), 27-29. 